\title{
Comparative Review of Three Approaches to Biofuel Production from Energy Crops as Feedstock in a Developing Country
}

\author{
Amin Nikkhah ${ }^{\mathrm{a}, \mathrm{b}^{*}}$, M. El Haj Assad ${ }^{\mathrm{c}}$, Kurt A. Rosentrater ${ }^{\mathrm{d}}$, Sami Ghnimi ${ }^{\mathrm{b}, \mathrm{e}}$, Sam Van Haute ${ }^{\mathrm{a}, \mathrm{b}}$ \\ ${ }^{a}$ Faculty of Bioscience Engineering, Ghent University, Coupure Links 653, 9000 Ghent, Belgium \\ E-mail address: Amin.Nikkhah@ugent.be \\ ${ }^{\mathrm{b}}$ Department of Environmental Technology, Food Technology and Molecular Biotechnology, Ghent \\ University Global Campus, Incheon, South Korea \\ ' SREE Department, University of Sharjah, P O Box 27272, Sharjah, United Arab Emirates \\ E-mail address: massad@ @harjah.ac.ae \\ ${ }^{\mathrm{d}}$ Department of Agricultural and Biosystems Engineering, Iowa State University, Ames, IA 50011, USA \\ karosent@iastate.edu \\ e Bioengineering and Microbial Dynamic at Food Interfaces, EA 3733, University of Lyon 1 - ISARA \\ Lyon), 23 rue Jean Baldassini, F69364, Lyon Cedex 07, France \\ sghnimi@isara.fr
}

\begin{abstract}
This study is a comparative evaluation of three approaches to biofuel production from energy crops including biogas, bioethanol and biodiesel to ascertain which one is the most effective and more energy-efficient than the others. Moreover, the potential of biofuel production from the best option was studied. For this purpose, biogas generation from corn silage, bioethanol generation from corn, and biodiesel production from peanuts in Iran (as a case study) were studied. The results revealed that $10,683.36 \mathrm{~m}^{3}$ of biogas, $2.53 \mathrm{~m}^{3}$ of bioethanol and $0.70 \mathrm{~m}^{3}$ of biodiesel could be produced per each hectare of energy crops. The total greenhouse gas emissions for each MJ energy generation of biogas, bioethanol and biodiesel were 0.01, 0.04 and $0.03 \mathrm{kgCO}_{2} \mathrm{eq}$, respectively. Accordingly, the total annual biogas potential from corn silage (as the best option) in Iran is $3,953.74$ million $\mathrm{m}^{3}$, which is equivalent to 1515.94 million barrels of oil.
\end{abstract}

Keywords: Biodiesel, Bioethanol, Biogas, Energy crop, Renewable energy 


\section{Nomenclature}

\begin{tabular}{|llll|}
\hline Acronyms & & & \\
BOE & Barrels of oil equivalent & $\mathrm{L}$ & Liter \\
$\mathrm{CH}_{4}$ & Methane & $\mathrm{kg}$ & kilogram \\
$\mathrm{CO}_{2}$ & Carbon dioxide & $\mathrm{km}$ & Kilometer \\
eq & Equivalent & $\mathrm{MJ}$ & Megajoule \\
$\mathrm{GHG}$ & Greenhouse gas & $\mathrm{m}^{3}$ & Cubic meter \\
$\mathrm{GJ}$ & Gigajoule & $\mathrm{UK}$ & United Kingdom \\
ha & Hectare & & \\
$\mathrm{t}$ & tonne & & \\
\hline
\end{tabular}

\section{Introduction}

On the one hand, fossil fuel-based sources are limited and they are being consumed faster than they can be reproduced (Ghadiryanfar et al., 2016; Moheimani and Parlevliet, 2013). On the other hand, the environmental consequences of consumption of fossil fuel resources are huge (Nikkhah et al., 2016a). Thus, replacement of a portion of fossil fuel with renewable-based resources is an urgent necessity (Fiala and Bacenetti, 2012; Pedraza, 2015).

In this regard, biomass is considered as one of the most promising renewable energy resources (Arumugam et al., 2016; Kim et al., 2016), which accounted for 59\% of total renewable-based resources in 2015 in the European Union (Scarlat et al., 2015). The globally produced biomass energy equivalent was estimated 8 times higher than the world total energy requirement (Alavijeh and Yaghmaei, 2016).

Energy crops are one of the main resources of biomass (Testa et al., 2016). There are many ways to generate energy from this resource (Eryilmaz et al., 2016; Moreda, 2016; Karimi Alavijeh et al., 2016), but the main commercial types are biogas, biodiesel and bio-ethanol (Hijazi et al., 2016). Comparing various energy crops (feedstock) systems in terms of energy efficiency and greenhouse gas (GHG) emissions can help in deciding how to transform to sustainable biofuel production systems. In this study, biogas generation from corn silage, 
bioethanol generation from corn, and biodiesel fuel production from peanuts in Iran (as a case study) were studied.

\section{Biogas generation}

Biogas-a renewable fuel- is generated from anaerobic breakdown of various biological feedstocks through synergistic metabolic activities of hydrolytic, acidogenic, and methanogenic microorganisms (Kaur and Phutela, 2016; Sheets et al., 2017). Biogas consists of around 60\% methane $\left(\mathrm{CH}_{4}\right), 40 \%$ carbon dioxide $\left(\mathrm{CO}_{2}\right)$, and around 2000 ppm hydrogen sulphide $\left(\mathrm{H}_{2} \mathrm{~S}\right)$ as the main impurity (Villadsen et al., 2019). Capturing methane in the biogas production process contributes positively to reduction of $\mathrm{CH}_{4}$ emissions and also the captured methane could be used as a renewable energy source to all applications designed for natural gas (Atelge et al., 2018; Kapdi et al., 2005; Noorollahi et al., 2015).

Global biogas production in the world increased from $0.28 \mathrm{EJ}$ in 2000 to $1.28 \mathrm{EJ}$ in 2014, with the volume of 59 billion $\mathrm{m}^{3}$ biogas (equaling 35 billion $\mathrm{m}^{3}$ methane) (Scarlat et al., 2018). The biogas generation status in some leading countries is shown in Table 1.

Corn is cultivated largely for biogas production in some countries all over the world (Nkemka et al., 2015). Germany and Italy cultivate more than 2,282,000 and 1,172,000 hectares of corn a year, respectively in order to be co-digested in large farm biogas plants (Casati, 2013; Bacentti et al., 2014). 


\section{Table 1}

The status of biogas generation in some countries (Kummamuru, 2015; Statista, 2017; Scarlat et al., 2018; Nikkhah et al., 2019)

\begin{tabular}{lcc}
\hline Country & Year & Biogas generation (billion $\mathrm{m}^{3}$ ) \\
\hline Brazil & 2013 & 0.29 \\
Canada & 2014 & 0.79 \\
China & 2014 & 15 \\
Germany & $2013 / 14$ & 13.5 \\
India & 2014 & 0.81 \\
Korea & 2013 & 0.43 \\
Thailand & 2014 & 1.3 \\
The Netherlands & 2012 & 0.52 \\
UK & 2013 & 3.16 \\
United states & 2014 & 8.48 \\
\hline
\end{tabular}

\section{Bioethanol production}

Bioethanol is considered as a renewable, and green combustible liquid fuel as alternative to gasoline (Thangavelu et al., 2016). It is easily used as oxygenated portion in gasoline for cleaner combustion (Thangavelu et al., 2016). Bioethanol production process includes treatment, enzyme hydrolysis, fermentation, recovery and the refining process (Wei et al., 2014; Gupta and Verma, 2015). Bioethanol as a fuel was initiated during the global fuel crisis in the 1970s and the capacity of its production rose from less than one billion L in 1975, to 39 billion L in 2006 due to its wide application in many sectors (Sirajunnisa and Surendhiran, 2016). Table 2 shows the world's largest ethanol producers in 2014.

Bioethanol is primarily generated from agricultural products with high content of sugar or starch, i.e. corn (Ho et al., 2014). Corn is widely grown around the globe, and globally, 817 
million tons of it was produced in 2009, more than rice (678 million tons) and wheat (682 million tons) (Koçar and Civaş, 2013).

\section{Table 2}

World's largest ethanol producers in 2014 (Renewables global status report, 2015)

\begin{tabular}{lcc}
\hline Country & Ethanol production (billion L) & Change relative to 2013 (\%) \\
\hline United States & 54.3 & +3.9 \\
Brazil & 26.5 & +1.6 \\
Germany & 0.9 & +0.6 \\
China & 2.8 & +0.3 \\
Argentina & 0.7 & +0.8 \\
Indonesia & 0.1 & +0.9 \\
France & 1 & +0.1 \\
Netherlands & 0.4 & +0.2 \\
Thailand & 1.1 & +0.4 \\
Canada & 1.8 & +0.1 \\
Belgium & 0.6 & +0.2 \\
Spain & 0.4 & +0.1 \\
Poland & 0.2 & +0.1 \\
Colombia & 0.4 & No change \\
Australia & 0.2 & -0.1 \\
\hline
\end{tabular}

\section{Biodiesel production}

Biodiesel -an alternative fuel for diesel- may be applied in conventional diesel engines without any major hardware alteration (Murugesanet al., 2009; Zhang et al., 2016). "Bio” implies its bio and renewable source, and "diesel" displays its application as fuel for diesel-based engines (Canakci and Özsezen, 2005). Biodiesel can be produced from oil seeds like peanut, canola, soybeans and sunflower through the process of transesterification (Ardebili et al., 2011). 
It could be an optimum alternative fuel in some countries such as Germany, Italy, France and Turkey (Eryilmaz et al., 2016). Fig. 1 demonstrates the largest biodiesel producers in the world in 2014.

Oil seeds are one of the remarkable resources for biodiesel generation (Gui et al., 2008). In this regard, peanut is known as one of the main resources of oilseeds for biodiesel production and peanut-based biodiesel was the first biofuel to power a diesel engine (Hogan et al., 2017). The advantages of biodiesel are biodegradability, renewability, higher flash point, and absence of sulfur and aromatic compounds (Kralova et al., 2010). However, when the source of its production is oil seeds, production of feedstock necessitates consumption of some inputs such as diesel fuel and chemical fertilizers that can contribute to the GHG emissions (Nikkhah et al., 2016b).

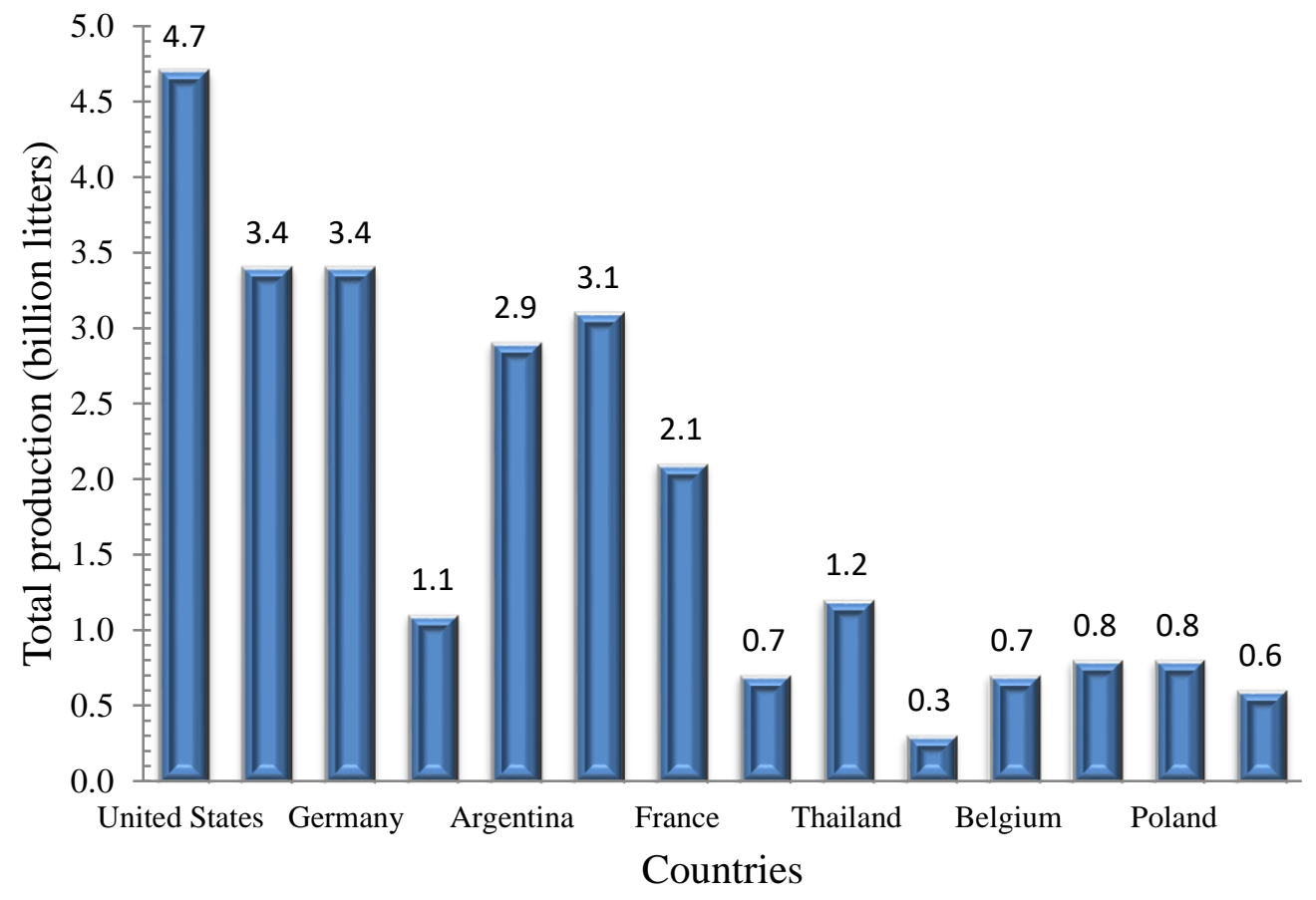

Fig. 1. World's largest biodiesel producers in 2014 (Hajjari et al., 2017) 


\section{Comparing the green technologies to generate energy}

The yields of corn silage, corn and peanuts production were adapted from literature review which are cited in Table 3. After that, the conversion coefficients were used to calculate the amount of biofuel and energy generation per hectare of farm. Table 3 displays the possible amounts of biofuel production from various technologies based upon cultivation of one hectare of different energy crops. The produced volumes were $10,683.36 \mathrm{~m}^{3}$ of biogas, $2.53 \mathrm{~m}^{3}$ of bioethanol and $0.70 \mathrm{~m}^{3}$ of biodiesel. The energy content of biogas generation from corn silage, bioethanol from corn and biodiesel from peanut were determined to be 267084.00, 26786.58 and 59,204.61 $\mathrm{MJha}^{-1}$, respectively. The results clearly illustrated that the net energy from biogas generation using corn silage was higher than that of the two other systems of biofuel production.

\section{Table 3}

The potential of different technologies to energy generation from energy crops

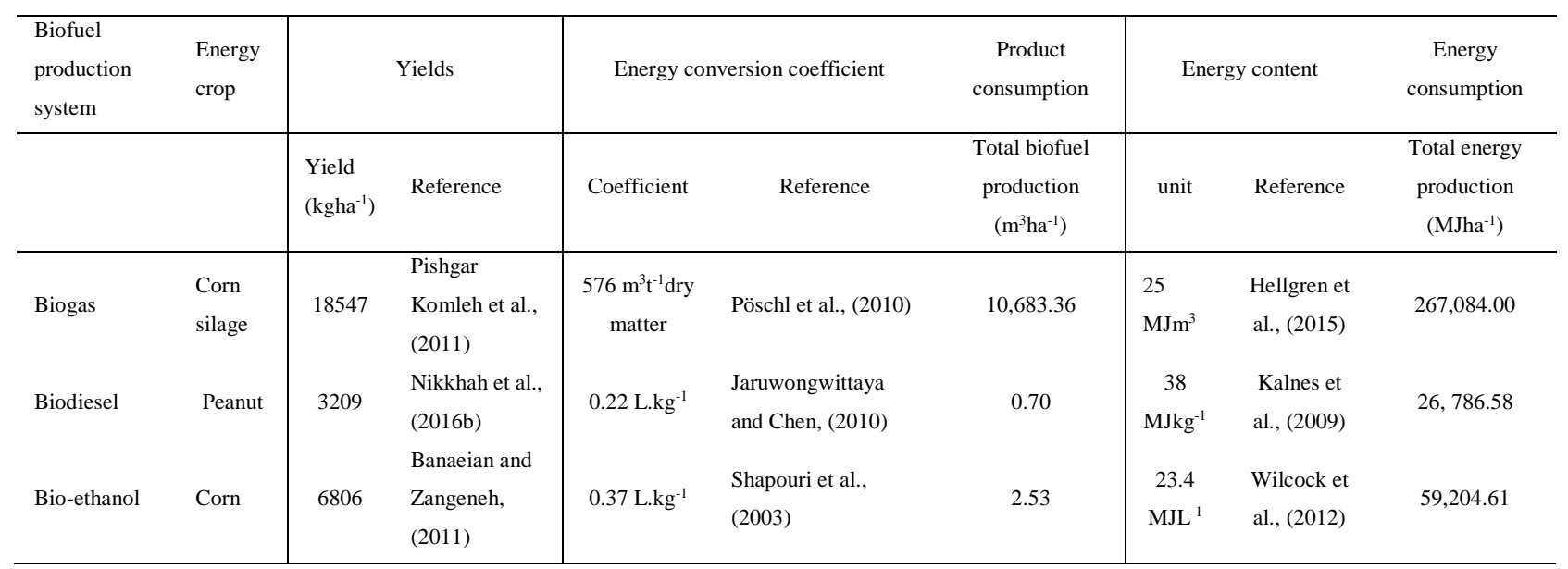

Figure 2 illustrates the barrels of oil equivalent (BOE) for each biofuel. The energy yield per hectare of corn silage to generate biogas was $43.1 \mathrm{BOE}$; then were 9.5 and 4.3 for bioethanol and biodiesel, respectively. 


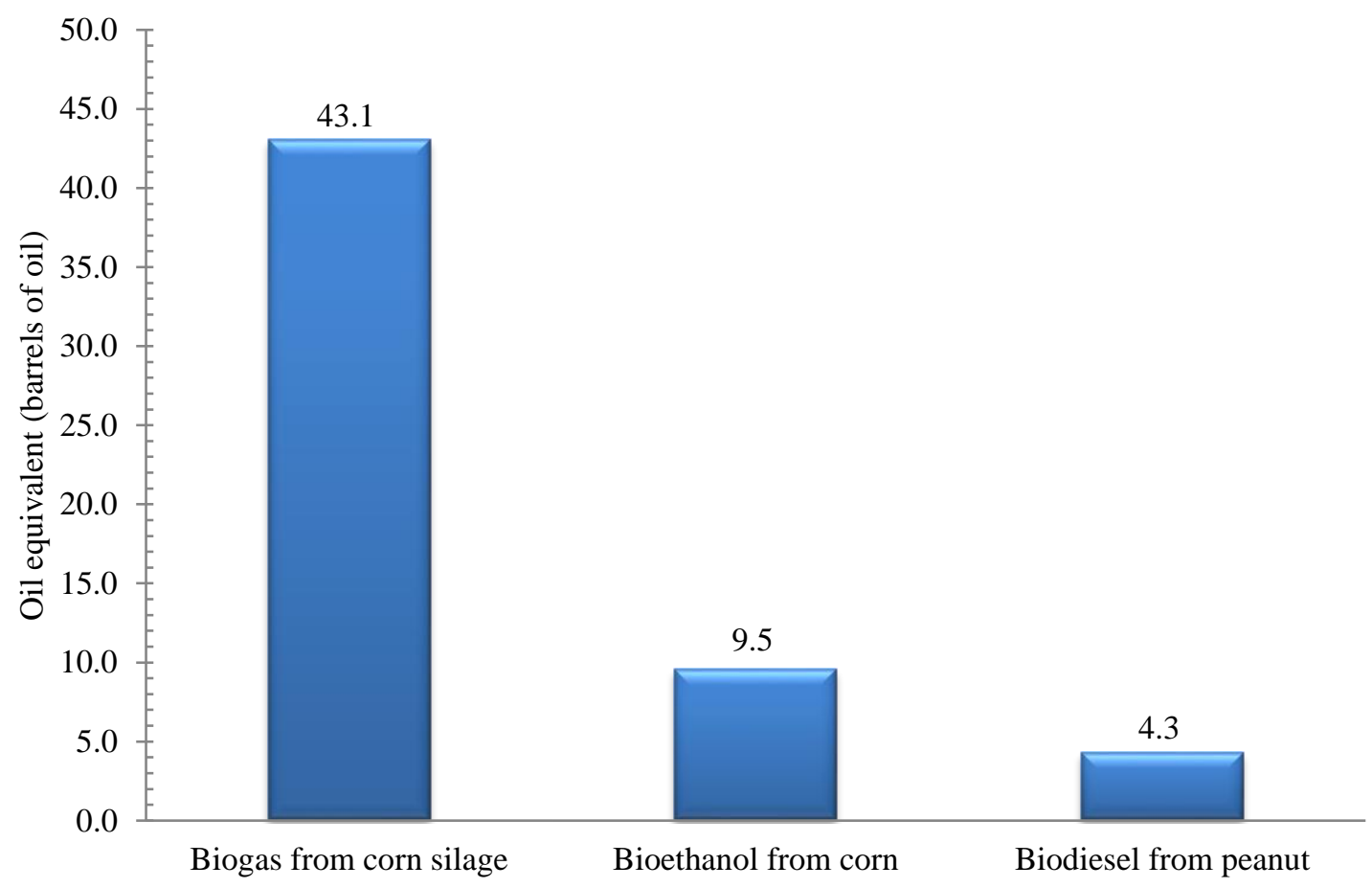

Fig. 2. Potential barrels of oil equivalent per hectare for each biofuel

Fig 3 illustrates the distance that a typical car can travel feeding with various biofuels (the biofuels are obtained from one hectare of energy crop) assuming the consumption rate of ten L of gasoline per $100 \mathrm{~km}$. The distances that a car can travel using biogas, bioethanol and biodiesel fuels were rouhgly estimated to be $62,000,14,000$ and $6,000 \mathrm{~km}$, respectively. It means that generated biogas from one hectare of corn silage has the greatest potential to be used as transportation fuel compared to bioethanol and biodiesel. Biogas is applied as an environmentally-efficient transportation fuel in some countries (Hamad et al., 2014; Raboni and Urbini, 2014). The European Union also has set a goal to increase the biofuel consumption; more specificly, $10 \%$ of fuels consumed in the transportation sector should be biofuels-based in 2020 , and after 2020, the percentage should further increase (Uusitalo et al., 2013). Moreover, based on the the Paris agreement, Iran has agreed for mitigating its GHG emissions (Ahmad et al., 2017). 
Thus, application of upgraded biogas instead of fossil fuels in the transportation sector could contribute to GHG emissons mitigation. In Sweden, biogas consumption since 2002 in urban transport alone has mitigated $\mathrm{CO}_{2}$ emissions by $9000 \mathrm{t}$ per year (Makareviciene et al., 2013).
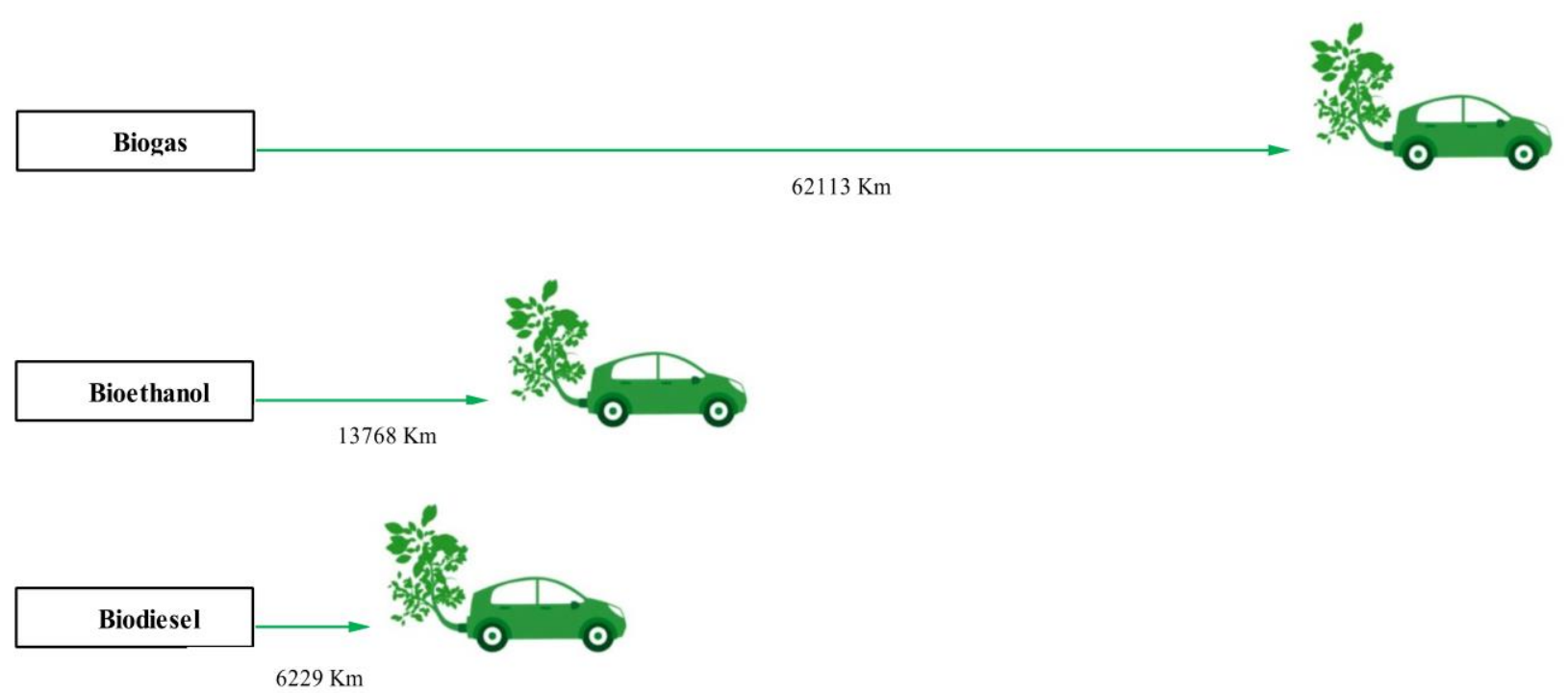

Fig. 3. The distance a car can travel using various biofuels (average fuel consumption was assumed to be $10 \mathrm{~L} / 100 \mathrm{~km}$ )

\section{Net energy comparison}

Table 4 summarizes the energy inputs for energy crops production. Agricultural machineries were the greatest energy consumers during corn production. Bacentti et al., (2013) reported that diesel fuel consumption is the main contributor to global warming in corn production systems in Italy. The greatest energy consumption of peanut production in Iran was attributed to diesel fuel, followed by chemical fertilizers.

The energy productivity to generate biogas, bioethanol and biodiesel were $0.15 \mathrm{~m}^{3} \mathrm{MJ}^{-1}, 0.05$ $\mathrm{LMJ}^{-1}$ and $0.04 \mathrm{LMJ}^{-1}$, respectively. The net energy for producing biogas, bioethanol and biodiesel were determined to be $198,156,6,629$ and 7,379 $\mathrm{MJha}^{-1}$, respectively. The results 
revealed that the biogas production from some crops, such as corn silage is the most energy efficient. For its generation, various processes are employed that may be divided in dry and wet fermentation approaches (Weiland, 2010). Berglund and Börjesson, (2006) investigated the energy performance of biogas generation. They concluded that the energy input for producing biogas corresponds to $20-40 \%$ of the total energy content of produced biogas. Jankowskia et al. (2016) evaluated the efficiency of energy consumption in biogas generation using corn, sweet sorghum, giant miscanthus, Virginia fanpetals, Amur silver grass, and alfalfa with timothy grass grown in Poland. They concluded that giant miscanthus was the most energy-efficient crop (25.0\%), followed by corn (15.8\%). Cvetković et al. (2014) claimed that corn silage is widely used as a co-substrate in biogas plants built on the farms in Serbia.

\section{Table 4}

Energy consumption and energy indices of energy crop production

\begin{tabular}{|c|c|c|c|c|c|c|}
\hline \multirow[b]{2}{*}{ Inputs } & \multicolumn{2}{|c|}{$\begin{array}{c}\text { Corn silage } \\
\text { (Pishgar Komleh et al., } \\
\text { 2011) }\end{array}$} & \multicolumn{2}{|c|}{$\begin{array}{c}\text { Corn } \\
\text { (Banaeian and Zangeneh, } \\
\text { 2011) }\end{array}$} & \multicolumn{2}{|c|}{$\begin{array}{c}\text { Peanut } \\
\text { (Emadi et al., 2015) }\end{array}$} \\
\hline & $\begin{array}{l}\text { Average } \\
\left(\mathrm{MJ} \mathrm{ha}^{-1}\right)\end{array}$ & $\begin{array}{c}\text { Percentage } \\
(\%)\end{array}$ & $\begin{array}{l}\text { Average } \\
\left(\mathrm{MJ} \mathrm{ha}^{-1}\right)\end{array}$ & $\begin{array}{c}\text { Percentage } \\
(\%)\end{array}$ & $\begin{array}{l}\text { Average } \\
\left(\mathrm{MJ} \mathrm{ha}^{-1}\right)\end{array}$ & $\begin{array}{c}\text { Percentage } \\
(\%)\end{array}$ \\
\hline Diesel fuel & 10800 & 16 & 12867 & 24 & 9714 & 50 \\
\hline $\begin{array}{l}\text { Agricultural } \\
\text { machineries }\end{array}$ & 28944 & 42 & 15575 & 29 & 2184 & 11 \\
\hline Chemical fertilizers & 19550 & 28 & 5646 & 33 & 3715 & 19 \\
\hline Electricity & - & - & - & - & 2065 & 11 \\
\hline Water & 6372 & 9 & 2927 & 6 & & \\
\hline Biocide & & & 683 & 1 & 219 & 1 \\
\hline Seeds & 3178 & 5 & 2773 & 5 & 331 & 2 \\
\hline Farmyard manure & & & 183 & 1 & & \\
\hline Human labor & 86 & 0.12 & 591 & & 1179 & 6 \\
\hline Total energy inputs & 68928 & - & 52575 & - & 19407 & - \\
\hline Energy productivity & 0.15 & - & 0.05 L.MJ $^{-1}$ & - & 0.04 L.MJ $^{-1}$ & - \\
\hline
\end{tabular}


$\mathrm{m}^{3} \mathrm{MJ}^{-1}$

Net energy

198156.00

6629.61

7379.22

Figure 4 displays the net energy for different technologies per hectare of energy crops. The net energy per hectare of corn silage to generate biogas is equal to 32.0 barrels of oil. The net energy per hectare of bioethanol and biodiesel production were determined to be 1.1 and 1.2 barrels of oil, respectively.

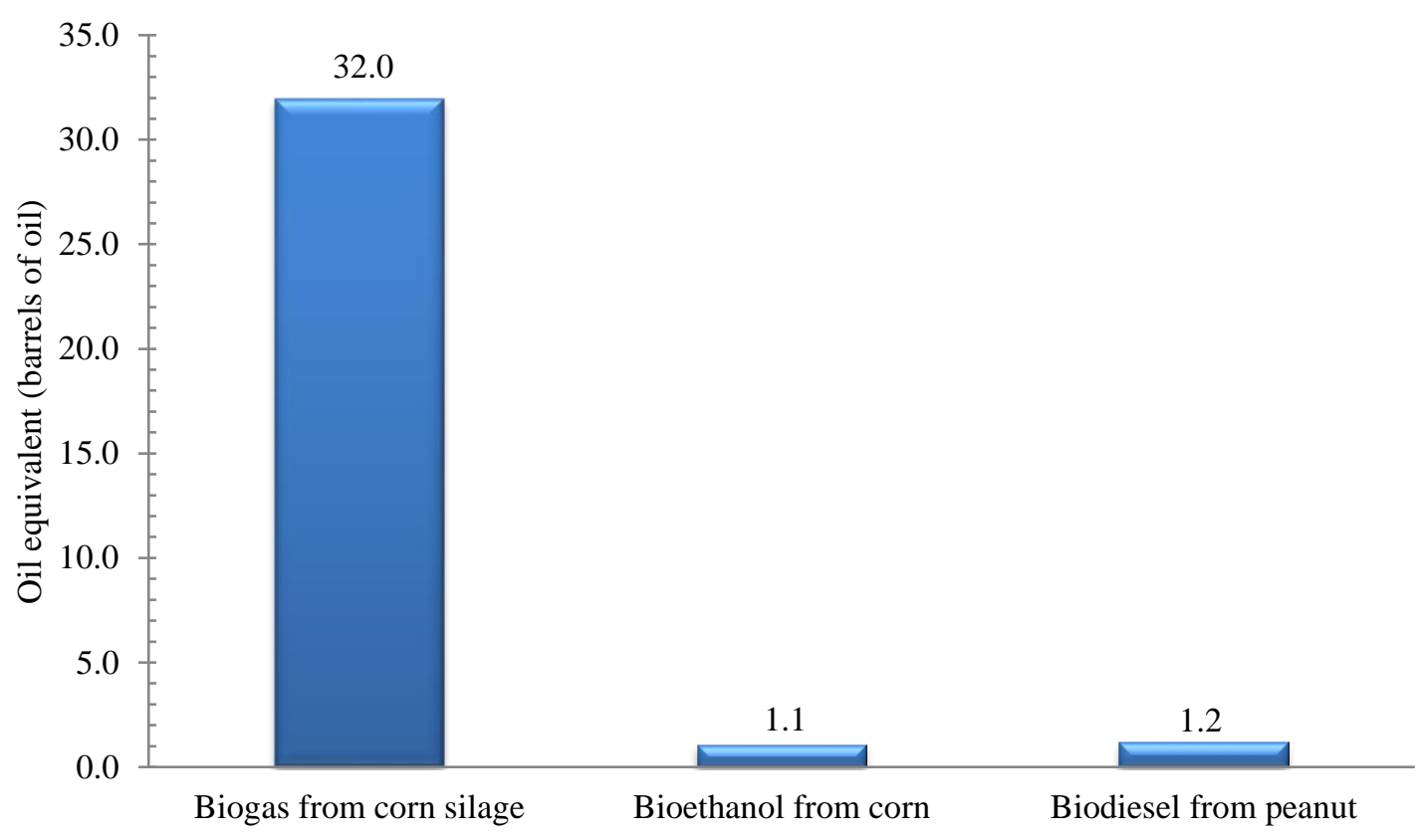

Fig. 4. The net energy produced by different technologies (per each hectare)

\section{Comparison of greenhouse gas emissions}

The raw data related to inputs-output production of corn silage was adapted from Pishgar Komleh et al. (2011), corn from Banaeian and Zangeneh, (2011), and peanut from Nikkhah et al., (2016b). Then, the GHG emissions coefficients were used to compute the corresponding GHG emission of each input. The GHG emissions for each hectare of energy crops production were calculated by equation 1 (based on Eren et al., 2019). 
GHG emissions $=\sum_{i=1}^{n} R(i) \times E F(i)$

where $\mathrm{R}(\mathrm{i})$ is the amount of input $\mathrm{i}$ consumption per hectare, and EF(i) is the GHG emission coefficient of input i $\left(\mathrm{kgCO}_{2} \mathrm{eq}\right)$.

Table 5 shows the GHG emissions calculated in this study from the investigated energy crop production systems. The results highlighted that the total GHG emissions footprint from potential feedstock production of biogas, bioethanol and biodiesel production were 2989, 2159 and $822 \mathrm{kgCO}_{2}$ eq ha ${ }^{-1}$, respectively. The GHG emissions for each MJ energy generation of biogas, bioethanol and biodiesel were determined to be $0.01,0.04$ and $0.03 \mathrm{kgCO}_{2} \mathrm{eq} \mathrm{ha}^{-1}$, respectively. It implies that the total GHG emissions to generate one MJ of biogas were lower than those of bioethanol and biodiesel technologies. Moreover, the GHG emissions per net energy ratio of biogas, bioethanol and biodiesel production were determined to be $0.02,0.33$ and $0.11 \mathrm{kgCO}_{2}$ eq $\mathrm{MJ}^{-1}$, respectively. González-García et al. (2013) evaluated three different energy crops such as corn, wheat, and triticale to generate biogas in Italy. The best results were reported for corn in most impact categories (González-García et al., 2013). Börjesson et al. (2015) studied the crop-based biogas production from six agricultural crops to be used as vehicle fuel. The results showed that ley crop-based biogas systems contributed to the largest GHG mitigation followed by corn, wheat, hemp, triticale and sugar beet. Overall, in all the studied cases, biogas consumption in the transportation sector has led to mitigation of GHG emissions compared to fossil transportation fuels (Uusitalo et al., 2014). 


\section{Table 5}

GHG emissions from the production of energy crops to generate energy

\begin{tabular}{|c|c|c|c|c|c|c|}
\hline & \multicolumn{2}{|c|}{ Corn silage } & \multicolumn{2}{|c|}{ Corn } & \multicolumn{2}{|c|}{ Peanut } \\
\hline Inputs & $\begin{array}{c}\text { Average } \\
\left(\mathrm{kg} \mathrm{CO}_{2} \mathrm{eq}\right. \\
\left.\mathrm{ha}^{-1}\right)\end{array}$ & $\begin{array}{c}\text { Percentage } \\
(\%)\end{array}$ & $\begin{array}{c}\text { Average } \\
\left(\mathrm{kg} \mathrm{CO}_{2} \mathrm{eq} \mathrm{ha}^{-1}\right)\end{array}$ & $\begin{array}{c}\text { Percentage } \\
(\%)\end{array}$ & $\begin{array}{l}\text { Average } \\
\left(\mathrm{MJ} \mathrm{ha}^{-1}\right)\end{array}$ & $\begin{array}{c}\text { Percentage } \\
(\%)\end{array}$ \\
\hline Diesel fuel & 624 & 21 & 632 & 29 & 476.12 & 57.90 \\
\hline $\begin{array}{l}\text { Agricultural } \\
\text { machineries }\end{array}$ & 2055 & 69 & 1106 & 51 & 155.04 & 18.86 \\
\hline Chemical fertilizers & 310 & 10 & 326 & 15 & 71.61 & 8.71 \\
\hline Electricity & - & - & - & & 105.27 & 12.80 \\
\hline Biocide & - & - & 18 & 1 & 14.26 & 1.73 \\
\hline Farmyard manure & - & - & 77 & 4 & - & - \\
\hline $\begin{array}{l}\text { Total GHG } \\
\text { emissions }\end{array}$ & 2989 & - & 2159 & & 822 & - \\
\hline Energy productivity & 0.01 & - & 0.04 & - & 0.03 & - \\
\hline$\frac{\text { GHG emissions }}{\text { Net energy }}$ & 0.02 & - & 0.33 & - & 0.11 & - \\
\hline
\end{tabular}

\section{Potential of biogas production from corn silage}

Table 6 shows the amounts of corn silage production in various provinces of Iran and their biogas yields. The greatest potential for biogas production were attributed to Fars (14\%), followed by Khuzestan province (12\%). Tehran province with a share of $11 \%$ was the third largest potential producer of biogas from corn silage. Figure 5 displays an atlas of annual potential biogas generation from corn silage in Iran.

The results showed that total potential yield of biogas was 3954 million $\mathrm{m}^{3}$ and its energy content was 98,843,613 GJ. The amount of biogas production from corn in Poland was reported to be 551 million $\mathrm{m}^{3}$ per annum (Igliński et al., 2015). Mohammadi Maghanaki et al. (2013) claimed that the amount of biogas production from animal wastes, agricultural wastes, municipal wastes and industrial and municipal wastewater in Iran can generate 16146 million $\mathrm{m}^{3}$. Annually 
81.5-279.4 million $\mathrm{m}^{3}$ of biogas could be produced from food industries in Iran (Iran Renewable Energy Organization, 2013). 74,946 tons of animal-based wastes are available each year in Iran and It could generate 8,668 million $\mathrm{m}^{3}$ of biogas (Mohammadi Maghanaki et al., 2013). There are different views about energy generation from different resources in Iran. On the one hand, Iran is considered as the world's fourth highest producer of crude oil and natural gas (Nikkhah et al., 2015). It has large amount of non-renewable energy resources and 99 percent of energy generation of Iran comes from non-renewable resources (Nikkhah, 2018). On the other hand, Iran was reported as the biggest $\mathrm{CO}_{2}$ emitter among the Middle East countries (Alshehry and Belloumi, 2014; Alizadeh et al., 2015), and environmental impacts are a major concern in Iran. Renewable energy generation fromenergy cropscan increase the share of renewable-based energy in Iran's energy production and contributing to the environmental impacts mitigation.

\section{Table 6}

Amounts of corn silage production in various provinces of Iran, and their potential biogas yield

\begin{tabular}{|c|c|c|c|c|c|}
\hline Province & $\begin{array}{l}\text { Cultivated area } \\
\text { (ha) (Ministry of } \\
\text { Jihad-e- } \\
\text { Agriculture of } \\
\text { Iran, 2019) }\end{array}$ & $\begin{array}{r}\text { Production (t) } \\
\text { (Ministry of } \\
\text { Jihad-e- } \\
\text { Agriculture of } \\
\text { Iran, 2019) }\end{array}$ & $\begin{array}{l}\text { Biogas yield } \\
\qquad\left(\mathrm{m}^{3}\right)\end{array}$ & $\begin{array}{l}\text { Energy content } \\
\text { (GJ) }\end{array}$ & Percentage \\
\hline Alborz & 8,433 & 418059 & 168561389 & 4214035 & 4.26 \\
\hline Ardabil & 10,892 & 434204 & 175071053 & 4376776 & 4.43 \\
\hline Bushehr & 388 & 25385 & 10235232 & 255880.8 & 0.26 \\
\hline $\begin{array}{l}\text { Chaharmahal } \\
\text { and Bakhtiari }\end{array}$ & 3,060 & 167986 & 67731955 & 1693299 & 1.71 \\
\hline $\begin{array}{l}\text { East } \\
\text { Azerbaijan }\end{array}$ & 3,565 & 159439 & 64285805 & 1607145 & 1.63 \\
\hline Fars & 23,435 & 1334748 & 538170394 & 13454260 & 13.61 \\
\hline Golestan & 8,650 & 334574 & 134900237 & 3372506 & 3.41 \\
\hline Guilan & 36 & 567 & 228614 & 5715.36 & 0.01 \\
\hline Hamedan & 2,850 & 156750 & 63201600 & 1580040 & 1.60 \\
\hline Hormozgan & 148 & 8310 & 3350592 & 83764.8 & 0.08 \\
\hline Illam & 2,491 & 70577 & 28456646 & 711416.2 & 0.72 \\
\hline Isfahan & 17,595 & 912638 & 367975642 & 9199391 & 9.31 \\
\hline
\end{tabular}




\begin{tabular}{|c|c|c|c|c|c|}
\hline Kerman & 4,759 & 239896 & 96726067 & 2418152 & 2.45 \\
\hline Kermanshah & 3,500 & 146582 & 59101862 & 1477547 & 1.49 \\
\hline Khuzestan & 21,846 & 1207915 & 487031328 & 12175783 & 12.32 \\
\hline Kohgiluyeh & 239 & 6631 & & & \\
\hline and Boyer- & & & 2673619 & & 0.07 \\
\hline Ahmad & & & & 66840.48 & \\
\hline Kurdistan & 192 & 8430 & 3398976 & 84974.4 & 0.09 \\
\hline Lorestan & 2,198 & 90230 & 36380736 & 909518.4 & 0.92 \\
\hline Markazi & 7,386 & 331343 & 133597498 & 3339937 & 3.38 \\
\hline Mazandaran & 3,290 & 79807 & 32178182 & 804454.6 & 0.81 \\
\hline North & 598 & 29696 & 11073427 & & 030 \\
\hline Khorasan & & & 11973421 & 299335.7 & 0.30 \\
\hline Qazvin & 21,980 & 1105922 & 445907750 & 11147694 & 11.28 \\
\hline Qom & 1,367 & 50570 & 20389824 & 509745.6 & 0.52 \\
\hline Razavi & 16,526 & 762756 & 307543219 & & 778 \\
\hline Khorasan & & & & 7688580 & \\
\hline Semnan & 2,244 & 86375 & 34826400 & 870660 & 0.88 \\
\hline Sistan and & 4,110 & 167419 & 67503341 & & 171 \\
\hline Baluchestan & & & & 1687584 & \\
\hline South & 840 & 31045 & 12517344 & & 032 \\
\hline Khorasan & & & & 312933.6 & \\
\hline $\begin{array}{l}\text { Southpart of } \\
\text { Kerman }\end{array}$ & 929 & 33539 & 13522925 & 338073.1 & 0.34 \\
\hline Tehran & 22,345 & 1082155 & 436324896 & 10908122 & 11.04 \\
\hline West & 5,738 & 273948 & 110455834 & & 270 \\
\hline Azerbaijan & & & & 2761396 & \\
\hline Yazd & 317 & 16644 & 6710861 & 167771.5 & 0.17 \\
\hline Zanjan & 930 & 31776 & 12812083 & 320302.1 & 0.32 \\
\hline Iran & 202,985 & 9805914 & 3953744525 & 98843613 & 100 \\
\hline
\end{tabular}




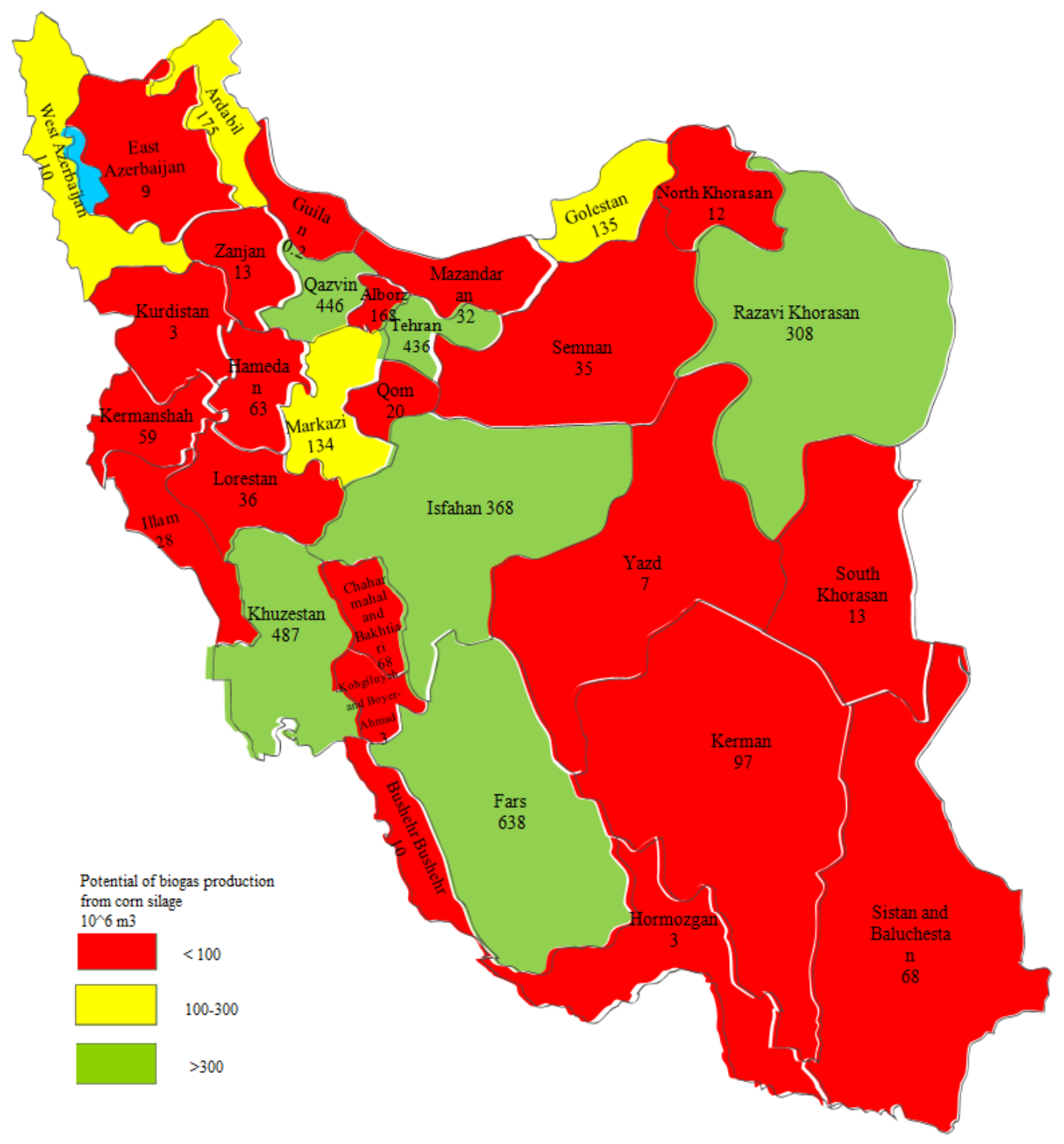

Fig. 5. Atlas of annual potential biogasproduction from corn silage in Iran. * the figure was generated using the data calculated in this study

The biogas generation potential from corn silage in Iran is equal to 15,941,241 barrels of oil per year. Iran's biomass potential is approximately 140 million barrels of crude oil equivalent (Noorollahi et al., 2015). It is concluded that consideration of energy crops like corn silage for biogas generation in Iran could have a remarkable impact on the energy matrix. Overall, 
according to the results, it can be well argued that corn silage biogas plans are energy-efficient as well as environmentally feasible as a long-term perspective.

\section{Conclusions and future work}

This study evaluated the potential of energy production from some energy crops feedstocks and their GHG emissions. It can be concluded that biogas production from corn silage is the most energy efficient way for energy generation compared to the other investigated approaches. This study also provided an atlas of annual potential biogas production from corn silage in Iran. Accordingly, total potential yield of biogas from corn silage in Iran was 3954 million $\mathrm{m}^{3}$, equal to 15.94 million barrels of oil. Further studies should be carried out on the economic analysis of biofuel production from corn silage in this region.

\section{Acknowledgment}

The authors would like to acknowledge the support received from Ghent University Global

Campus. A part of the financial support was provided by the Department of Agricultural and Biosystems Engineering, Iowa State University, USA, is kindly acknowledged.

\section{References}

1. Ahmad, N., Hamid, I., Kazmi, S.T.H. 2017. Beyond COP 21: What did Asian countries pledge in the Paris Agreement?

2. Alizadeh, R., Majidpour, M., Maknoon, R., Salimi, J., 2015. Iranian energy and climate policies adaptation to the Kyoto protocol. Int. J. Environ. Res. 9, 853-864.

3. Alshehry, A.S. Belloumi, M., 2014. Investigating the Causal Relationship between Fossil Fuels Consumption and Economic Growth at Aggregate and Disaggregate Levels in Saudi Arabia. IJEEP. 4, 531-545. 
4. Ardebili, M.S. Ghobadian, B. G. Najafi, G., Chegeni, A., 2011. Biodiesel production potential from edible oil seeds in Iran. Renew. Sust. Energ. Rev. 15, 3041-3044.

5. Arumugam, N., Anandakumar, S., 2016. Mini review on Corncob biomass: A potential resource for value-added metabolites. Eur. J. Exp. Biol, 6, 9-13.

6. Atelge, M.R., Krisa, D., Kumar, G., Eskicioglu, C., Nguyen, D.D., Chang, S.W., Atabani, A.E., Al-Muhtaseb, A.H. and Unalan, S., 2018. Biogas production from organic waste: recent progress and perspectives. WASTE BIOMASS VALORI. 1-22.

7. Bacenetti, J., Fusi, A., Guidetti, R., Fiala, M., 2013. Life Cycle Assessment of maize cultivation for biogas production. J. Agric. Eng. 44, 579-582.

8. Bacenetti, J., Fusi, A., Negri, M., Guidetti, R., Fiala, M. 2014. Environmental assessment of two different crop systems in terms of biomethane potential production. Sci. 466, 1066-1077.

9. Banaeian, N. and Zangeneh, M., 2011. Study on energy efficiency in corn production of Iran. Energy. 36(8), 5394-5402.

10. Berglund, M., Börjesson, P., 2006. Assessment of energy performance in the life-cycle of biogas production. Biomass and Bioenergy. 30, 254-266.

11. Börjesson, P., T. Prade, T., Lantz, M., Björnsson, L., 2015. Energy crop-based biogas as vehicle fuel-the impact of crop selection on energy efficiency and greenhouse gas performance. Energies. 8, 6033-6058.

12. Canakci, M., Özsezen, A.N., 2005. Evaluating waste cooking oils as alternative diesel fuel. Gazi University Journal of Science. 18, 81-91.

13. Cvetković, S., Radoičić, T.K., Vukadinović, B., Kijevčanin, M., 2014. Potentials and status of biogas as energy source in the Republic of Serbia. Renew. Sust. Energ. Rev. 31, 407-416.

14. D. Casati, 2013. Annatadavverodifficile urge risalire la china. Terra Vita. 6, 40-4. 
15. Emadi, B., Nikkhah, A., Khojastehpour, M. and Payman, H., 2016. Effect of farm size on energy consumption and input costs of peanut production in Guilan province of Iran. Journal of Agricultural Machinery. 5(1), 217-227.

16. Eren, O., Baran, M.F. and Gokdogan, O., 2019. Determination of greenhouse gas emissions (ghg) in the production of different fruits in Turkey. FEB-FRESENIUS ENVIRONMENTAL BULLETIN, 28 (1), 464-472.

17. Eryilmaz, T., Yesilyurt, M.K., Cesur, C., Gokdogan, O., 2016. Biodiesel production potential from oil seeds in Turkey. Renew. Sust. Energ. Rev. 58 (2016) 842-851.

18. Fiala, M. Bacenetti, J., 2012. Model for the economic, energy and environmental evaluation in biomass productions. J. Agric. Eng. 43, 26-35.

19. Ghadiryanfar, M. Rosentrater, K.A. Keyhani, A. Omid, M., 2016. A review of macroalgae production, with potential applications in biofuels and bioenergy. Renew. Sust. Energ. Rev. $54,473-481$.

20. González-García, S., Bacenetti, J., Negri, M.M., Fiala, M., Arroja, L., 2013. Comparative environmental performance of three different annual energy crops for biogas production in Northern Italy. J. Clean. Prod. 43 (2013) 71-83.

21. Gui, M.M., Lee, K.T., Bhatia, S., 2008. Feasibility of edible oil vs. non-edible oil vs. waste edible oil as biodiesel feedstock. Energy. 33, 1646-1653.

22. Gupta, A., Verma, J.P., 2015. Sustainable bio-ethanol production from agro-residues: a review. Renew. Sust. Energ. Rev. 41, 550-567.

23. Hajjari, M., Tabatabaei, M., Aghbashlo, M., Ghanavati, H., 2017. A review on the prospects of sustainable biodiesel production: A global scenario with an emphasis on waste-oil biodiesel utilization. Renew. Sust. Energ. Rev. 72, 445-464. 
24. Hamad, T.A., Agll, A.A., Hamad, Y.M., Sheffield, J.W., 2014. Solid waste as renewable source of energy: current and future possibility in Libya. Case Stud. Therm. Eng. 4, 144-152.

25. Hellgren, L., Kavvada, O., Phelps, C., 2015. Energy Management in Wastewater Treatment Systems: Biogas Energy Recovery Management Application. Energy Systems and Control. $1-13$.

26. Hijazi, O. S., Munro, S., Zerhusen, B., Effenberger, M., 2016. Review of life cycle assessment for biogas production in Europe. Renew. Sust. Energ. Rev. 54, 1291-1300.

27. Ho, D.P., Ngo, H.H., Guo, W. 2014. A mini review on renewable sources for biofuel. Bioresour. Technol. 169, 742-749.

28. Hogan, D., Desai, A., Soloiu, V., 2017. Peanut based biodiesel production in georgia: an economic feasibility study. Int J Ind Syst Eng. 5, 12-22.

29. Igliński, B., Buczkowski, R., Cichosz, M., 2015. Biogas production in Poland-Current state, potential and perspectives. Renew. Sust. Energ. Rev. 50, 686-695.

30. Jankowski, K.J., Dubis, B., Budzyński, W.S., Bórawski, P., Bułkowska, K., 2016. Energy efficiency of crops grown for biogas production in a large-scale farm in Poland. Energy. 109, 277-286.

31. Jaruwongwittaya, T. and Chen, G., 2010. A review: renewable energy with absorption chillers in Thailand. Renew. Sust. Energ. Rev. 14(5), 1437-1444.

32. Kalnes, T.N., Koers, K.P., Marker, T., Shonnard, D.R., 2009. A technoeconomic and environmental life cycle comparison of green diesel to biodiesel and syndiesel. ENVIRON PROG SUSTAIN. 28(1), 111-120. 
33. Kana, E.G., Oloke, J.K., Lateef, A., Adesiyan, M.O., 2012. Modeling and optimization of biogas production on saw dust and other co-substrates using artificial neural network and genetic algorithm. Renew. Energy. 46, 276-281.

34. Kapdi, S.S., Vijay, V.K., Rajesh, S.K., Prasad. R., 2005. Biogas scrubbing, compression and storage: perspective and prospectus in Indian context, Renew. Energy. 30, 1195-1202.

35. Karimi-Alavijeh, M.K., Yaghmaei, S., 2016. Biochemical production of bioenergy from agricultural crops and residue in Iran. Waste Manag. 52, 375-394.

36. Kaur, K., Phutela, U.G., 2016. Enhancement of paddy straw digestibility and biogas production by sodium hydroxide-microwave pretreatment. Renew. Energy. 92, 178-184.

37. Kim, H., Shimizu, T., Kourakata, I., Takahashi, Y. 2016. Energy recovery from mushroom culture waste and the use of its ash as fertilizer. Energy Technology Roadmaps of Japan. $455-458$.

38. Koçar, G., Civaş, N., 2013. An overview of biofuels from energy crops: Current status and future prospects. Renew. Sust. Energ. Rev. 28, 900-916.

39. Komleh, S.P., Keyhani, A., Rafiee, S.H. and Sefeedpary, P., 2011. Energy use and economic analysis of corn silage production under three cultivated area levels in Tehran province of Iran. Energy. 36(5), 3335-3341.

40. Kralova, I., Sjöblom, J., 2010. Biofuels-renewable energy sources: a review. J DISPER SCI TECHNOL. 31, 409-425.

41. Kummamuru, B.V., 2015. WBA Global Bioenergy Statistics. World Bioenergy Association, 2015. 
42. Makareviciene, V., Sendzikiene, E., Pukalskas, S., A. Rimkus, A., Vegneris, R., 2013. Performance and emission characteristics of biogas used in diesel engine operation. ENERG CONVERS MANAGE. 75, 224-233.

43. Ministry of Jihad-e-Agriculture of Iran. 2019. Annual agricultural statistics. Available from: http://www.maj.ir.

44. Moreda, I.L., 2016. The potential of biogas production in Uruguay. Renew. Sust. Energ. Rev. 54. $1580-1591$.

45. Nikkhah, A., B. Emadi, B., Khojastehpour, M., Payman, S.H., 2016b. GHG emissions footprint from potential feedstock production of biodiesel fuel (Case Study), Iranian Journal of Biosystems Engineering. 47, 207-213. (In Persian).

46. Nikkhah, A., Emadi, B., Firouzi, S., 2015. Greenhouse gas emissions footprint of agricultural production in Guilan province of Iran, SUSTAIN ENERGY TECHN. 12, 10-14.

47. Nikkhah, A., Emadi, B., Soltanali, H., Firouzi, S., Rosentrater, K.A., Allahyari, M.S., 2016a. Integration of Life Cycle Assessment and Cobb-Douglas Modeling for the Environmental Assessment of Kiwifruit in Iran. J. Clean. Prod. 137, 843-849.

48. Nikkhah, A., Khojastehpour, M. and Abbaspour-Fard, M.H., 2019. Valorization of municipal solid wastes through biogas production in Iran. energyequipsys. 7(1), 57-65.

49. Nikkhah. A., 2018. Life cycle assessment of the agricultural sector in Iran (2007-2013). ENVIRON PROG SUSTAIN. 37(5), 1750-1757

50. Nkemka, V.N. Gilroyed, B., Yanke, J., Gruninger, R., Vedres, D., McAllister, T., X. Hao, X., 2015. Bioaugmentation with an anaerobic fungus in a two-stage process for biohydrogen and biogas production using corn silage and cattail. Bioresour. Technol. 185, 79-88. 
51. Noorollahi, Y. M., Kheirrouz, M., Asl, H.F., Yousefi, H., Hajinezhad, A., 2015. Biogas production potential from livestock manure in Iran. Renew. Sust. Energ. Rev. 50, 748-754.

52. Pedraza, J.M., 2015. The Current Situation and Perspectives on the Use of Renewable Energy Sources for Electricity Generation. In Electrical Energy Generation in Europe. 55-92.

53. Pöschl, M., Ward, S. and Owende, P., 2010. Evaluation of energy efficiency of various biogas production and utilization pathways. Appl. Energy. 87(11), 3305-3321.

54. Raboni, M., Urbini, G., 2014. Production and use of biogas in Europe: a survey of current status and perspectives. Revista ambiente \& agua. 9, 191-202.

55. Renewables 2015. Global status report. page 129. Accessed on 23th March 2017

56. Scarlat, N., Dallemand, J.F. and Fahl, F., 2018a. Biogas: Developments and perspectives in Europe. Renew. Energy. 129, pp.457-472.

57. Scarlat, N., Dallemand, J.F., Monforti-Ferrario, F., Banja, M., Motola, V., 2015. Renewable energy policy framework and bioenergy contribution in the European Union - an overview from National Renewable Energy Action Plans and Progress Reports. Renew. Sust. Energy Rev. 51, 969-985.

58. Shapouri, H., Duffield, J.A., Wang, M., 2003. The energy balance of corn ethanol revisited. Transactions of the ASAE. 46, 959.

59. Sheets, J.P., Lawson, K., Ge, X., Wang, L., Yu, Z., Li, Y., 2017. Development and evaluation of a trickle bed bioreactor for enhanced mass transfer and methanol production from biogas. Biochem. Eng. J. 122, 103-114.

60. Sirajunnisa, A.R., Surendhiran, D., 2016. Algae-A quintessential and positive resource of bioethanol production: A comprehensive review. Renew. Sust. Energ. Rev. 66, 248-267. 
61. Statista - The portal for statistics. 2017. Available at: https://www.statista.com/statistics/481840/biogas-production-worldwide-by-key-country

62. Testa, R., Foderà, M.A.M., Di Trapani, A.M., Tudisca, S., Sgroi, F., 2016. Giant reed as energy crop for Southern Italy: An economic feasibility study. Renew. Sust. Energ. Rev. 58, $558-564$.

63. Thangavelu, S.K., Ahmed, A.S., Ani, F.N., 2016. Review on bioethanol as alternative fuel for spark ignition engines. Renew. Sust. Energ. Rev. 56, 820-835.

64. Uusitalo, V., Havukainen, J., Manninen, K., Höhn, J., Lehtonen, E., Rasi, S., Soukka, R., Horttanainen, M., 2014. Carbon footprint of selected biomass to biogas production chains and GHG reduction potential in transportation use. Renew. Energy. 66, 90-98.

65. Uusitalo, V., Soukka, R., Horttanainen, M., Niskanen, A., Havukainen, J., 2013. Economics and greenhouse gas balance of biogas use systems in the Finnish transportation sector. Renew. Energy. (51), 132-140.

66. Villadsen, S.N., Fosbøl, P.L., Angelidaki, I., Woodley, J.M., Nielsen, L.P. and Møller, P., 2019. The Potential of Biogas; The Solution to Energy Storage. ChemSusChem, 12(10), 2147-2153.

67. Wei, P., L.H. Cheng, L.H., Zhang, L., X.H. Xu, X.H., Chen, H.L., Gao, C.J., 2014. A review of membrane technology for bioethanol production. Renew. Sust. Energ. Rev. 30, 388-400.

68. Weiland, P., 2010. Biogas production: current state and perspectives. Appl Microbiol Biotechnol. 85, 849-860.

69. Wilcock, W., 2005. Energy in natural processes and human consumption-some numbers. Accessed on 24th March 2017, Available at: www.ocean.washington.edu/courses/envir215/energynumbers.pdf 